\title{
Prospects for Using Entomopathogenic Nematodes to Control the Vine Mealybug, Planococcus ficus, in South African Vineyards
}

\author{
P.D. le Vieux, A.P. Malan* \\ Department of Conservation Ecology and Entomology, Stellenbosch University, Stellenbosch, Private Bag X1, Matieland \\ 7602, Stellenbosch, South Africa.
}

Submitted for publication: June 2014

Accepted for publication: July 2014

Key words: Entomopathogenic nematode, field trials, olfactometry, persistence, Steinernema yirgalemense

\begin{abstract}
In South Africa, the most common method of mealybug control has been the use of chemical insecticides. Entomopathogenic nematodes (EPNs) of the of the families Heterorhabditidae and Steinernematidae potentially can be used within an integrated pest management scheme to control Planococcus ficus, the vine mealybug, which occurs on all parts of grapevine, including the roots. When Steinernema yirgalemense was applied to the soil of two vineyards with $P$. ficus, contained in pierced Eppendorf tubes, buried at a depth of $15 \mathrm{~cm}$ in the soil, mortalities of up to $50 \%$ were obtained after $48 \mathrm{~h}$. The persistence of $S$. yirgalemense, measured using codling moth larval mortality was found to be zero in one vineyard, while in the other it was $70 \%, 12$ weeks after application. Tests were conducted to establish the production of scavenger deterrent factors by $H$. zealandica and $S$. yirgalemense. Of the cadavers that were presented six days after nematode infection, $49 \%$ of the $H$. zealandica- and $60 \%$ of the $S$. yirgalemense-infected cadavers were left intact. Olfactometry tests indicated a significant difference concerning the number of $S$. yirgalemense infective juveniles (IJs) that were attracted to damaged Vitis vinifera roots and $P$. ficus, indicating active movement of the IJs and the attractive ability of organic compounds produced by the roots. This study shows that EPNs, and specifically $S$. yirgalemense, have promising potential as biological control agents for the control of $P$. ficus soil populations, and investigates some influential factors affecting EPNs as biocontrol agents in the agro-ecosystem.
\end{abstract}

\section{INTRODUCTION}

Planococcus ficus (Signoret) (vine mealybug) is currently regarded as both the dominant mealybug species and as a major pest insect of the South African table grape and wine industries (Walton, 2003). It not only causes cosmetic damage to grape bunches, but also lowers grape production levels by transmitting various plant diseases and viruses, resulting in it characteristically being more economically damaging than any other mealybug species (Haviland et al., 2005; Daane et al., 2008; Holm, 2008; Negrisoli et al., 2013).

To date, the most common method of mealybug control in South Africa has been the use of chemical insecticides such as organophosphates (Walton et al., 2004; Daane et al., 2006; Holm, 2008). Mealybugs are difficult to control using chemicals, as they hide deep in crevices, under bark and on roots, where chemicals cannot reach (Walton \& Pringle, 2004b). Another problem concerning the use of chemical pesticides is the ability of mealybugs to rapidly build up resistance (Flaherty et al., 1982; Walton \& Pringle, 2004b; Franco et al., 2009). An alternative to using chemicals in controlling $P$. ficus is to use entomopathogenic nematodes (EPNs) within an integrated pest management (IPM) scheme. The current rise of interest in the use of EPNs within an IPM scheme is a progressive and positive move towards reducing chemical pesticide use in the pursuit of sustainable agricultural practice (Le Vieux \& Malan, 2013a).

EPNs of the families Heterorhabditidae and Steinernematidae are found naturally in soils, where they are lethal parasites of a wide range of insects that have soil-dwelling life stages (Foltan \& Puza, 2009; Gulcu et al., 2012). Heterorhabditids and steinernematids both have obligatory symbiotic associations with bacteria of the genera Photorhabdus and Xenorhabdus respectively (Boemare, 2001; Ehlers, 2001; Griffin et al., 2005). Both families have a life stage that is free-living and non-feeding, known as an infective juvenile (IJ), which is well adapted to long-term survival in the soil, where it seeks out an insect host (Ehlers, 2001). Once the IJ locates a suitable host, it enters the host body via natural openings and then moves through the thin lining of the intestine, releasing its associated bacteria in the haemocoel and killing the host within 24 to $48 \mathrm{~h}$ (Gulcu et al., 2012). Some species, which currently are produced commercially, are used as effective biological control agents (Kaya \& Gaugler, 1993; Hazir et al., 2003). Le Vieux

*Corresponding author: E-mail address: apm@sun.ac.za

Acknowledgements: The authors would like to thank Winetech and the National Research Foundation (NRF-THRIP TP2011060100026) for funding the project. We would also like to thank Prof D Nel, for assistance with the statistical analysis 
and Malan (2013b) conducted studies in the laboratory during which six South African nematodes species were tested. They established that Steinernema yirgalemense Nguyen, Tesfamariam, Gozel, Gaugler \& Adams, 2005 and Heterorhabditis zealandica Poinar, 1990 were the most effective in infecting and killing adult female P. ficus.

The use of EPNs is generally more suited to control soil-dwelling insect stages than above-ground insect pests (Wilson \& Gaugler, 2004). This is encouraging when considering the fact that the vine mealybug has a distinctive vertical seasonal movement on grapevines. Although the greater part of the population is found above ground, they also occur on vine roots down to a depth of $30 \mathrm{~cm}$ (Walton \& Pringle, 2004a; De Villiers, 2006). As a result, soil column tests were conducted by Le Vieux and Malan (2013b). Planococcus ficus individuals were buried $15 \mathrm{~cm}$ deep in river sand, with the resultant mean percentage mortality caused by $H$. zealandica and $S$. yirgalemense at $82 \%$ and $95 \%$ respectively.

Nematode infectivity in the soil is an important factor when nematodes are used as a biocontrol agent, and can be affected by many abiotic, biotic and application factors. A variety of abiotic factors, including soil moisture and texture, temperature and relative humidity have different effects on the pathogenicity, movement and persistence of different nematode species (Kung et al., 1990; 1991; Shapiro-Ilan et al., 2006). Biotic adversaries in the soil that reduce applied EPN numbers include a variety of organisms, such as protozoans, predacious mites, bacteria, nematophagous fungi, and other free-living and competitor nematodes (Kaya, 2002; Duncan et al., 2007; Campos-Herrera et al., 2011a; 2011b).

When using EPNs in an IPM scheme, it is important to determine the compatibility and interactions of the EPNs with agrochemicals such as pesticides (García del Pino \& Jové, 2005; Gutiérrez et al., 2008). A previous South African study, by Van Niekerk and Malan (2014), investigated the compatibility of two endemic nematodes, $S$. yirgalemense Nguyen and $H$. zealandica, with two biopesticides, Helicovir ${ }^{\mathrm{TM}}$ (nucleopolyhedrovirus) and Cryptogran ${ }^{\mathrm{TM}}$ (Cryptophlebia leucotreta granulovirus), two adjuvants (NuFilm- $\mathrm{P}^{\circledR}$ and $\mathrm{Zeba}^{\circledR}$ ) and one insecticide (Cyperphos 500 E.C. $\left.{ }^{\circledR}\right)$. They found no significant reduction in the levels of IJ infectivity in either of the nematode species when they were exposed to any of the formulated products.

The influence of symbiotic relationships within the agroecosystem, which may either hinder or aid the process of controlling the vine mealybug, requires acknowledgement. Mealybugs and ants are known to have a mutualistic symbiosis, whereby the ants obtain carbohydrate-rich honeydew from the mealybug, while in return providing it with protection, sanitation and transport (Mgocheki \& Addison, 2009). Thus, ants potentially can increase mealybug pest problems by interfering with the augmentative and natural biological control, through assisting in their dispersal, or through decreasing the EPN efficacy by means of scavenging on EPN-infected insect cadavers (Phillips \& Sherk, 1991; Baur et al., 1998; Daane et al., 2008). The most common pest ant species in South African vineyards include Linepithema humile (Mayr) (Argentine ant), Anoplolepis steingroeveri
(Forel) (black pugnacious ant), and Anoplolepis custodiens (Smith) (common pugnacious ant) (Addison, 2002).

Not much is known about the various searching behaviours of EPNs and the role of chemical communication in the soil, but it is believed that EPNs, of both genera, make use of chemoreception to find their insect hosts (Boff et al., 2001; Van Tol et al., 2001). EPNs have been found to respond to volatile host-associated cues, such as faeces and carbon dioxide $\left(\mathrm{CO}_{2}\right)$ (Lewis et al., 1993; Grewal et al., 1994; Lewis et al., 2006). In addition, certain stimuli that are released by healthy plant roots might signify a potential habitat for hosts, thus influencing EPN movement and behaviour (Bird \& Bird, 1986; Choo et al., 1989; Lei et al., 1992; Van Tol et al., 2001). Rasmann et al. (2005) and Van Tol et al. (2001) have identified that plants are not passive victims of herbivorous insects. The researchers in question have identified a tritrophic level of interaction, whereby the stimuli that are emitted from plants that have been damaged by insect herbivory provide the EPN, Heterorhabditis megidis Poinar, Jackson and Klein, 1987, with specific information regarding the presence of potential insect hosts. Rasmann et al. (2005) were the first to identify the insect-induced below-ground plant signal, $(E)$ - $\beta$-caryophyllene (released by maize roots), which strongly attracts $H$. megidis. De Waal et al. (2011) tested the host-seeking ability of six South African isolates, finding that none (including $S$. yirgalemense) displayed a positive attraction to codling moth (Cydia pomonella L.) larvae, apart from $H$. zealandica.

The main objectives of the current study were to establish the efficiency of controlling soil populations of $P$. ficus using EPNs in vineyards, while investigating factors that potentially might influence the efficacy of the EPNs. Factors concerned include the compatibility of simultaneously using EPNs with the pesticide imidacloprid $\left(\right.$ Confidor $\left.^{\circledR}\right)$, and the potential interference caused by scavenging ants, while investigating the possible influence of olfactory cues produced by grapevine roots on EPNs.

\section{MATERIALS AND METHODS \\ Source of nematodes and insects}

The IJ rearing and harvesting procedures were carried out according to Kaya and Stock (1997) using codling moth, Cydia pomonella (Linnaeus) (Lepidotera: Tortricidae), at room temperature $\left( \pm 25^{\circ} \mathrm{C}\right)$. IJs from the White trap were harvested within the first week of emergence and stored horizontally in 500-ml vented culture flasks containing approximately $150 \mathrm{ml}$ of distilled water at $14^{\circ} \mathrm{C}$. The nematodes were used within a month of harvesting. To aid in aeration and nematode survival during storage, the culture flasks were shaken weekly. The two local EPN species used, H. zealandica (SF 41) and S. yirgalemense (157-C), were originally obtained from previous local surveys. Cultures of them are maintained in the Stellenbosch University nematode collection (Malan et al., 2006; 2011). The two commercially available nematode species, Steinernema feltiae (Filipjev, 1934) Wouts, Mráček, Gerdin and Bedding, 1982 and Heterorhabditis bacteriophora Poinar, 1976, were stored at $4^{\circ} \mathrm{C}$ prior to use.

A laboratory colony of $P$. ficus was established and reared on butternuts at $25^{\circ} \mathrm{C}$. Codling moth eggs and 
artificial diet were obtained from Entomon Technologies (Pty) Ltd, Stellenbosch and reared to last-instar larvae under diapausing conditions [photoperiod 10:14 (L: D)], at $25^{\circ} \mathrm{C}$ and $60 \%$ humidity. They were then stored in the diet in a closed container in a cold room at $5^{\circ} \mathrm{C}$, until needed.

\section{Baseline sampling and soil properties}

Two study sites, Block A (Welgevallen, Stellenbosch University Experimental Farm) and Block B (Nietvoorbij, Agriculture Research Council ARC-Infruitech/Nietvoorbij) in Stellenbosch were selected for conducting the field trials. Block A is situated at $33^{\circ} 5628^{\prime \prime} \mathrm{S} ; 18^{\circ} 51^{\prime} 46^{\prime \prime} \mathrm{E}$, at an elevation of $117 \mathrm{~m}$ in the foothills of the surrounding mountains, while Block B is situated at $33^{\circ} 54^{\prime} 27^{\prime \prime} \mathrm{S} ; 18^{\circ} 52^{\prime} 12^{\prime \prime} \mathrm{E}$, at an elevation of $236 \mathrm{~m}$. Soil samples were collected from Block A and Block B and analysed by Bemlab (Western Cape, South Africa), which is a SANAS-accredited testing laboratory. A mechanical three-fraction analysis was undertaken to determine the soil classification, as well as the percentage of sand, clay and silt, the $\mathrm{pH}$, and the electrical conductivity (EC) of the two sites.

Soil samples close to each treatment vine (32 samples in total) were collected in $350 \mathrm{ml}$ plastic containers. Prior to nematode application, ten mealworms, Tenebrio molitor (Linnaeus), were placed in each container and left for seven days. Dead individuals were removed and placed on moist filter paper in a Petri dish, sealed with PARAFILM ${ }^{\circledR}$, and left to incubate at $25^{\circ} \mathrm{C}$ for a further $24 \mathrm{~h}$. They were then placed on White traps to test for the occurrence of native EPNs.

In-field soil application and infectivity of $S$. yirgalemense At both sites, vines in a randomised design were used, with four treatments, at concentrations of $0,20,40$ and $80 \mathrm{IJs} /$ $\mathrm{cm}^{2}$. Eight vines were used per treatment ( $n=32$ vines), with six rows of vines, of which the first and last vine, and the first and the last row, were left untreated so as to avoid any possible edge effects. Eight vines from each row were selected and alternate vines were treated.

Two perforated (with a heated surgical needle) $0.2 \mathrm{ml}$ Eppendorf tubes were tied together with cotton thread. After placing five adult female mealybugs in each tube, the respective lids were closed and the tubes were buried $15 \mathrm{~cm}$ deep in the soil, close to each treatment vine trunk. The thread was left extending above the soil to enable easy detection and retrieval.

An area of $80 \times 100 \mathrm{~cm}$ was measured around each treatment vine. The desired number of $S$. yirgalemense for each treatment was prepared in $200 \mathrm{ml}$ of water. Once the mealybugs in the tubes and four iButton temperature loggers were buried, the nematode suspensions were sprayed onto the soil using a hand-held spray bottle. Each treatment vine was watered with $10 \mathrm{~L}$ of water and one day later they were watered again (if no natural rainfall or irrigation had occurred in between). The mealybugs were removed from the soil after $48 \mathrm{~h}$. The mealybugs were rinsed with water, placed in small Petri dishes lined with moist filter paper and sealed with PARAFILM ${ }^{\circledR}$, placed in a growth chamber at 25 $\pm 2{ }^{\circ} \mathrm{C}$, and left to incubate at $25{ }^{\circ} \mathrm{C}$ for $24 \mathrm{~h}$. The mealybugs were then dissected to confirm infection.

\section{In-field soil persistence of $\boldsymbol{S}$. yirgalemense}

The same treatment vines from Block A and Block B were used to conduct persistence trials. However, instead of using $P$. ficus, codling moth larvae, with a high susceptibility to S. yirgalemense (De Waal et al., 2011), were used. Five perforated $0.2 \mathrm{ml}$ Eppendorf tubes were tied together with cotton thread, with a single larva being placed in each tube. The tubes were buried close to the treatment vine trunks, with the thread extending above the soil. Larvae were left in the soil for five days, watered only on the first day with $10 \mathrm{~L}$ of water, and then retrieved and placed on moist filter paper in a Petri dish. The dish was sealed with PARAFILM ${ }^{\circledR}$ and left to incubate for another $24 \mathrm{~h}$ at $25{ }^{\circ} \mathrm{C}$. After this, the larvae were dissected to confirm infection. This experiment was repeated at time intervals of one to six weeks after the date of EPN application.

\section{Laboratory persistence of $S$. yirgalemense and H. zealandica}

Sterilised river sand, prepared in a ratio of $1: 10 \mathrm{v} / \mathrm{v}$ of water and sand, was added to $250 \mathrm{ml}$ plastic containers and inoculated with $10 \mathrm{IJ} / \mathrm{cm}^{2}$ (1 $040 \mathrm{IJ} /$ container) in the centre of each container for both $S$. yirgalemense and $H$. zealandica. The containers were then placed in a large plastic bin, lined at the bottom with moist paper, closed with the lid and left in a room at $25^{\circ} \mathrm{C}$ for the duration of the experiment. Baiting was done by using ten codling larvae per tub for each month interval after initial IJ inoculation. Each bating session comprised two batches, with five containers for each batch, for both species and the control containers (which received no IJs), thus a total of 30 containers for each species treatment with a total of 420 containers. The codling moth larvae in the containers were left in a dark growth chamber at $25 \pm$ $2^{\circ} \mathrm{C}$ for $48 \mathrm{~h}$. Dead codling moth larvae were immediately dissected and checked for infection, while living individuals were rinsed and left in a dark growth chamber at $25 \pm 2{ }^{\circ} \mathrm{C}$ for another $48 \mathrm{~h}$ and then checked for infection if they were dead.

\section{Effects of imidacloprid on survival}

The survival of $S$. feltiae and $H$. bacteriophora (these two species, currently available as formulated products, will most probably be used in future large-scale field application) exposed to the insecticide imidacloprid was tested. The pesticide was prepared at twice the recommended dose. Suspensions of both nematode species were prepared at a concentration of $4000 \mathrm{IJs} / \mathrm{ml}$. Treatments contained a mixture of $1 \mathrm{ml}$ of nematode suspension in water and $1 \mathrm{ml}$ of the pesticide solution (to obtain the recommended dosage), which was added to a Petri dish, sealed with PARAFILM ${ }^{\circledR}$ and left in a growth chamber at $25 \pm 2{ }^{\circ} \mathrm{C}$. Controls contained $1 \mathrm{ml}$ of nematode suspension and $1 \mathrm{ml}$ of water. Five treatment and five control Petri dishes were prepared for both nematode species. Nematode survival was estimated by means of collecting $10 \mu \mathrm{l}$ samples from each Petri dish until 50 IJs were counted, of which the individuals were recorded as being either dead or alive. Samples were taken directly after preparation $(0 \mathrm{~h})$, and then again after 6,12 and $24 \mathrm{~h}$. 


\section{Effects of imidacloprid on virulence}

To establish the virulence of both nematode species postexposure to the insecticide, $5 \mathrm{ml}$ at $4000 \mathrm{IJs} / \mathrm{ml}$ of each nematode suspension were prepared and kept in a growth chamber for $24 \mathrm{~h}$ at $25 \pm 2{ }^{\circ} \mathrm{C}$. After $24 \mathrm{~h}$, the $5 \mathrm{ml}$ nematode/ pesticide solution was diluted in $1 \mathrm{~L}$ of distilled water in a measuring cylinder. Once the nematodes had settled to the bottom, excess liquid was siphoned off, leaving $10 \mathrm{ml}$ behind. The remaining $10 \mathrm{ml}$ was used to inoculate five Petri dishes, containing 10 codling moth larvae each, at a concentration of $100 \mathrm{IJs} /$ insect. Five control Petri dishes, containing 10 codling moth larvae each, received water only. They were kept for $48 \mathrm{~h}$ in a growth chamber at $25 \pm 2{ }^{\circ} \mathrm{C}$. The codling moth larvae were then assessed for infection by dissection. The experiment for both nematode species was repeated at a later date.

Ant deterrent factors of $\boldsymbol{H}$. zealandica and $S$. yirgalemense Ten Cydia pomonella larvae were placed in each of five $13 \mathrm{~cm}$ Petri dishes and lined with moist filter paper. Petri dishes were inoculated with $100 \mathrm{IJs} /$ larvae (1 $000 \mathrm{IJs}$ in total) and a second batch two days later, sealed with PARAFILM ${ }^{\circledR}$ and left in a dark growth chamber at $25 \pm 2{ }^{\circ} \mathrm{C}$ for four and six days respectively. The procedure was repeated for both $S$. yirgalemense and $H$. zealandica, while the control larvae were freeze-killed. Two shaded Argentine ant L. humile nests were identified and used as study sites. At each nest, 25 codling moth larvae cadavers infected with $H$. zealandica, 25 infected with $S$. yirgalemense and 25 freeze-killed larvae (control) were individually placed in single perforated PCR $0.2 \mathrm{ml}$ tubes. Eppendorf tubes were linked together alternatively by a thread and left for $24 \mathrm{~h}$ close to each nest. The cadavers were then taken back to the laboratory, where they were categorised into 'intact', 'bitten' and 'consumed'. The size of the holes in the tubes ensured that only ants could reach the treated cadavers. The procedure was repeated on a different date.

\section{Cue attraction response for $S$. yirgalemense}

A three-armed olfactometer was assembled. Three small holes were made in the sides of a $7 \mathrm{~cm}$ diameter Petri dish, with a single hole in the centre of the lid to fit the tip of an Eppendorf pipette. Three disposable plastic pipettes were cut to remove the centre column; the front $4 \mathrm{~cm}$ and the bulb were then reconnected. The Petri dish and the three modified pipettes were filled with sterilised river sand, prepared in a ratio of $1: 10 \mathrm{v} / \mathrm{v}$ of water and sand. The lid was placed on the Petri dish and was sealed with PARAFILM ${ }^{\circ}$. The tips of the three pipettes were inserted into the holes of the Petri dish. Of the three bulbs, the first was empty (control), the second contained 15 female $P$. ficus, and the third contained $0.5 \mathrm{~g}$ of $V$. vinifera roots cut into small $2 \mathrm{~cm}$ pieces. The experimental setup, containing the study subjects, was left for $6 \mathrm{~h}$ so as to allow a chemical gradient to develop in the sand. Approximately $2000 \mathrm{IJ}$ s of S. yirgalemense, concentrated in $100 \mu \mathrm{l}$ water, were pipetted through the hole made in the centre of the lid of the Petri dish, after which the hole was sealed. The apparatus was left in a dark growth chamber at $25 \pm 2{ }^{\circ} \mathrm{C}$ for $24 \mathrm{~h}$, after which the contents of each pipette arm were emptied separately into a Petri dish. The mealybugs were then removed, followed by rinsing of the inside of the arm and bulb. Water was added, and the IJs were counted with the aid of a Leica stereomicroscope. The mealybugs were then placed on moistened filter paper and left in an incubator for a further $48 \mathrm{~h}$, after which they were dissected and developed nematodes found in the olfactometer arm were counted and added to the total.

\section{Data analysis}

All statistical analyses were done using STATISTICA version 11 (StatSoft Inc., 2012). An analysis of variance (ANOVA) was used to analyse the data. A post hoc comparison of means was used employing Bonferroni's method or, when the residuals were not normally distributed, a bootstrap multicomparison of means was conducted with $95 \%$ confidence intervals (Efron \& Tibshirani, 1993). For the olfactometer test, an ANOVA was done, using a generalised linear model (GLZ) and assuming a Poisson distribution of the variables (counting variables), with a log link function. The Wald test was used as the test statistic. Data from different test dates were pooled if no significant differences were found between the data and the treatment.

\section{RESULTS}

\section{Baseline sampling and soil properties}

Of the soil samples taken close to the 32 vines used in each vineyard, $6.25 \%$ of those in Block A and $9.69 \%$ of those in Block B were naturally infected. These EPNs were identified, using molecular techniques (Nguyen et al., 2007), as $H$. bacteriophora. The bacteria of $H$. bacteriophora coloured the cadaver red, whereas $S$. yirgalemense coloured the cadaver yellow. No red cadavers were observed after treatment in any of the field trials. The soil analysis indicates (see Table 1) the differences in the soil properties between the two trial sites.

TABLE 1

Chemical and physical soil analysis of samples taken from Welgevallen (Block A) and Nietvoorbij (Block 2) vineyards in Stellenbosch.

\begin{tabular}{lccccccccc}
\hline Vineyard & EC (mS/m) & pH (KCl) & C (\%) & N (\%) & Clay (\%) & Silt (\%) & Sand (\%) & Classification & C:N ratio \\
\hline Block A & 10 & 5.8 & 0.25 & 0.03 & 23 & 18 & 59 & Lm* & 8.33 \\
Block B & 22 & 6.0 & 0.80 & 0.09 & 21 & 14 & 65 & SaKlLm** & 8.88 \\
\hline
\end{tabular}

*Loam; **Sand/Clay/Loam 
In-field soil application and infectivity of $S$. yirgalemense Block $A$

The soil temperature $15 \mathrm{~cm}$ below the soil surface during the $48 \mathrm{~h}$ post-nematode treatment was a mean of $24.2^{\circ} \mathrm{C}$, with a minimum of $15.6^{\circ} \mathrm{C}$ and a maximum of $32.1^{\circ} \mathrm{C}$. Analysing the data using a one-way ANOVA showed a significant effect between the treatments of $S$. yirgalemense at concentrations of 80, 40, 20 and $0 \mathrm{IJ} / \mathrm{cm}^{2}\left(\mathrm{~F}_{(3,28)}=7.7252 ; P<0.001\right)$. $P$. ficus mortalities differed for all treatments compared to the control, except for the concentration of $20 \mathrm{IJ} / \mathrm{cm}^{2}$, which obtained a mean mortality of $23 \% \pm 7 \%(P=0.3)$. The concentration of $80 \mathrm{IJs} / \mathrm{cm}^{2}$ was responsible for the greatest percentage of $P$. ficus mortality, at $50 \% \pm 10 \%$ (Fig. 1).

\section{Block B}

The soil temperature $15 \mathrm{~cm}$ below the soil surface during the $48 \mathrm{~h}$ post-nematode treatment was a mean of $23.8^{\circ} \mathrm{C}$, with a minimum of 17.6 and a maximum of $32.7^{\circ} \mathrm{C}$. Data analysed using a one-way ANOVA showed a significant effect between treatments of $S$. yirgalemense at concentrations of $80,40,20$ and $0 \mathrm{IJ} / \mathrm{cm}^{2}\left(\mathrm{~F}_{(3,28)}=5.9448, P=0.0028\right)$. P. ficus mortality differed for all treatments compared to the control, whereas $20 \mathrm{IJs} / \mathrm{cm}^{2}$ obtained a mean mortality of $28 \% \pm 11 \%$ $(P=0.075)$. The concentration of $80 \mathrm{IJ} / \mathrm{cm}^{2}$ was responsible for the greatest percentage of $P$. ficus mortality, at $52 \% \pm$ $12 \%$ (Fig. 2).

\section{In-field soil persistence of $S$. yirgalemense \\ Block $A$}

A two-way ANOVA comparing IJ concentrations (80, 40, 20 and $\left.0 \mathrm{IJs} / \mathrm{cm}^{2}\right)$ and weeks (1, 2, 4 and 12 weeks) post-S. yirgalemense application show no significant interactions when considering codling moth larval mortality $\left(\mathrm{F}_{(9,112)}=0.87904, P=0.546\right)$. Data from the three treatments was pooled and a one-way ANOVA showed significant effects between persistence over time, $\mathrm{F}_{(3,84)}=5.584 ; P=0.002$ ). No significant differences were found between week 1 and week 2 post-application; however, between week $2(93 \% \pm$ $3 \%)$ and week $4(72 \% \pm 8 \%)$, a significant $(P=0.035)$ lower persistence was found, while between week 4 and week 12 no significant difference in persistence was found of $S$. yirgalemense with regard to codling moth larval mortality (Fig. 3).

\section{Block B}

Data was analysed using a two-way ANOVA comparing IJ concentrations $\left(80,40,20\right.$ and $\left.0 \mathrm{IJs} / \mathrm{cm}^{2}\right)$ and weeks $(1,2$, 4 and 12 weeks) post-IJ application, showing no significant interactions when considering codling moth larvae mortality $\left(\mathrm{F}_{(9,112)}=1.5238 ; P=0.148\right)$ (Fig. 4). However, if the data from the three treatments were pooled, a one-way ANOVA showed significant lowered persistence with regard to codling moth larval mortality over time. A significant difference $(P=0.026)$ in mortality was found between week $1(59 \% \pm 6 \%)$ and week $4(19 \% \pm 6 \%)$. After 12 weeks, zero mortality for codling moth larvae was found.
Laboratory persistence of $S$. yirgalemense and H. zealandica

The results obtained from testing the laboratory persistence of the two species were pooled and analysed with a two-way ANOVA. Significant overall interactions were found between the species (two levels: $H$. zealandica and S. yirgalemense) and months (five levels: 0 to 6 months) $\left(\mathrm{F}_{(4,90)}=18.342\right.$; $P=<0.001)$. There was no significant difference in mortalities over the five dates for $S$. yirgalemense. By the fourth month the percentage mortality caused by $H$. zealandica differed

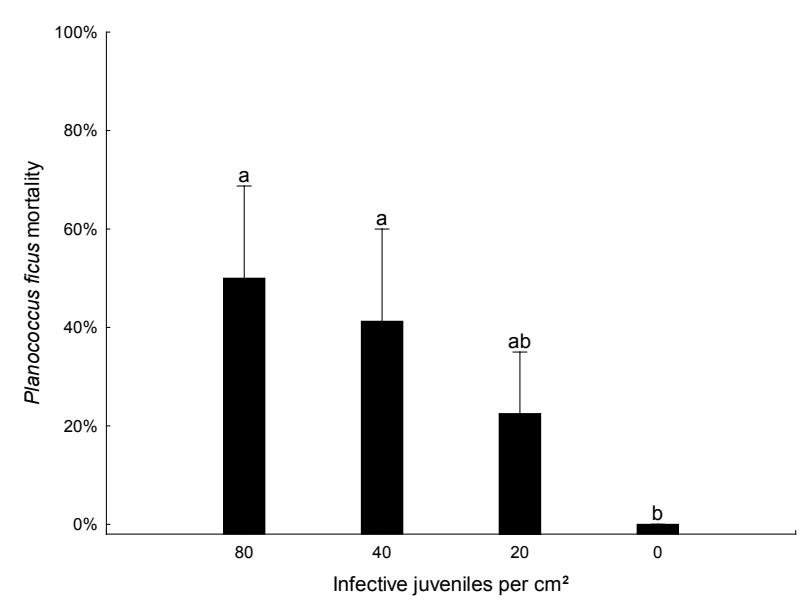

FIGURE 1

Percentage mortality ( $95 \%$ confidence interval) of Planococcus ficus buried $15 \mathrm{~cm}$ beneath the soil in the Welgevallen vineyard (Block A) with a $48 \mathrm{~h}$ exposure to Steinernema yirgalemense at concentrations of 80, 40, 20 and $0 \mathrm{IJs} / \mathrm{cm}^{2}$ (one-way ANOVA; $\mathrm{F}_{(3,28)}=7.7252 ; P<0.001$ ). Bars sharing a common letter are not significantly different.

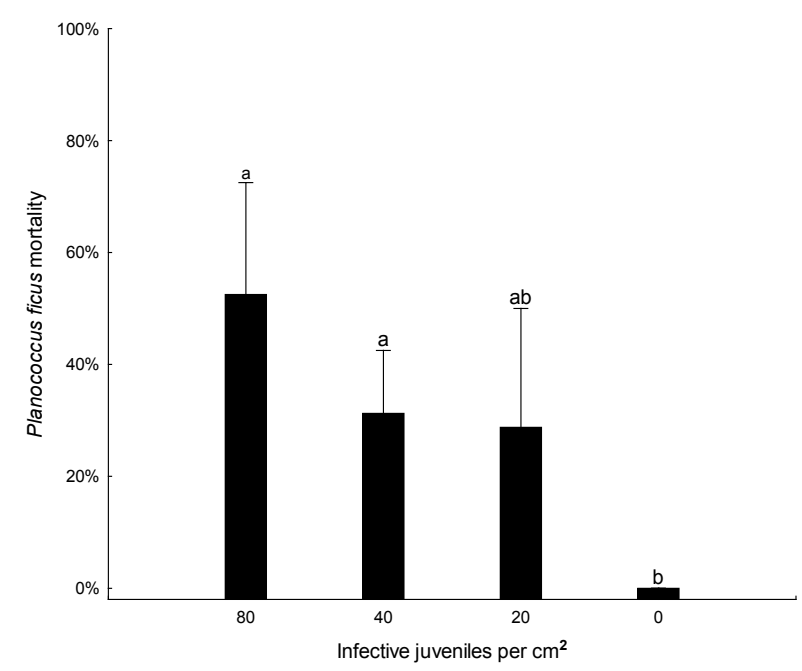

\section{FIGURE 2}

Percentage mortality (95\% confidence interval) of Planococcus ficus buried $15 \mathrm{~cm}$ beneath the soil in the Nietvoorbij vineyard (Block B) with a $48 \mathrm{~h}$ exposure to Steinernema yirgalemense at concentrations of 80, 40, 20 and $0 \mathrm{IJs} / \mathrm{cm}^{2}$ (one-way ANOVA; $\mathrm{F}_{(3,28)}=5.9448 ; P=0.0028$ ). Bars sharing a common letter are not significantly different. 
significantly from that of $H$. zealandica in the preceding months and the mortalities caused by $S$. yirgalemense in month four $(P<0.001)$. From 0 months to 6 months, codling moth larval mortalities due to $H$. zealandica were reduced from $100 \%$ to $5 \%$ (Fig. 5).

\section{Effects of imidacloprid on survival}

Data analysed with a three-way ANOVA showed no significant interaction between batches of $H$. bacteriophora (two levels: batch 1 and batch 2, used on separate dates), between periods (four levels: $0 \mathrm{~h}, 6 \mathrm{~h}, 12 \mathrm{~h}$ and $24 \mathrm{~h}$ ), and between treatments (two levels: Confidor ${ }^{\circledR}$ and water) $\left(\mathrm{F}_{(3,}\right.$ $\left.{ }_{64)}=0.0232 ; P=0.995\right)$. Pooled data from the two batches analysed with a two-way ANOVA, comparing the treatments and the hours of exposure, showed no significant difference in IJ mortalities ( $\mathrm{F}_{(3,72)}=0.048670 ; P=0.692$ ) (data not shown).

Data analysed with a three-way ANOVA showed no significant interaction between batches of $S$. feltiae (two levels: batch 1 and batch 2, used on separate dates), between periods (four levels: $0 \mathrm{~h}, 6 \mathrm{~h}, 12 \mathrm{~h}$ and $24 \mathrm{~h}$ ), and between treatments (two levels: imidacloprid and water) ( $\mathrm{F}_{(3,64)}$ $=0.19143 ; P=0.901)$. Pooled data from the two batches, analysed with a two-way ANOVA comparing the treatments and the hours of exposure, showed no significant difference in $\mathrm{IJ}$ mortalities $\left(\mathrm{F}_{(3,72)}=0.6263 ; P=0.6\right)$ between the two (data not shown).

\section{Effects of imidacloprid on virulence}

A two-way ANOVA showed no significant difference between batches of $H$. bacteriophora $\left(\mathrm{F}_{(2,24)}=3.2632\right.$; $P=0.055)$. Data from the two batches were pooled and analysed using a one-way ANOVA, resulting in a significant difference between the mortalities of the treatments $\left(\mathrm{F}_{(2,27)}=\right.$ $154.19 ; P<0.001)$. The water (control) treatment showed no mortality. No significant difference was found between the percentage mortality of codling moth larvae inoculated with $H$. bacteriophora exposed to imidacloprid for $24 \mathrm{~h}(88 \% \pm$ $3.8 \%$ mortality), and those with no previous exposure $(88 \%$ $\pm 5.9 \%$ mortality) $(P=1)$ (data not shown)

A two-way ANOVA showed no significant difference between batches of $S$. feltiae $\left(\mathrm{F}_{(2,24)}=2.94 ; P=0.07\right)$. Data from the two batches were pooled and analysed using a one-way ANOVA, resulting in a significant difference between the mortalities of the treatments $\left(\mathrm{F}_{(2,27)}=196.59\right.$; $P<0.001)$. The water (control) treatment had zero mortality. No significant difference was found between the percentage mortalities of codling moth inoculated with $S$. feltiae exposed to imidacloprid for $24 \mathrm{~h}(82 \% \pm 4.6 \%$ mortality $)$, and those with no previous exposure $(88 \% \pm 3.8 \%$ mortality $)(P=0.1)$ (data not shown).

Ant deterrent factors of $\boldsymbol{H}$. zealandica and $S$. yirgalemense A two-way ANOVA with a generalised linear model (GLZ) analysis (log-link function on a Poisson distribution) showed no significant difference in the number of intact $C$. pomonella cadavers after $24 \mathrm{~h}$ exposure to L. humile in the field. Analysis with a bootstrap multiple comparison, as well as with GLZ confidence intervals for the predicted means, gave similar results, as presented in Fig. 6. The number of intact cadavers post-infection was significantly less $(\mathrm{P}=0.033)$ at four days (four cadavers) than at six days (15 cadavers) postinoculation for $H$. zealandica. The number of intact cadavers did not differ significantly for four days (seven cadavers) or six days (12 cadavers) post-inoculation in the case of S. yirgalemense.

After $24 \mathrm{~h}$ exposure to L. humile, cadavers infected with $H$. zealandica and $S$. yirgalemense were categorised

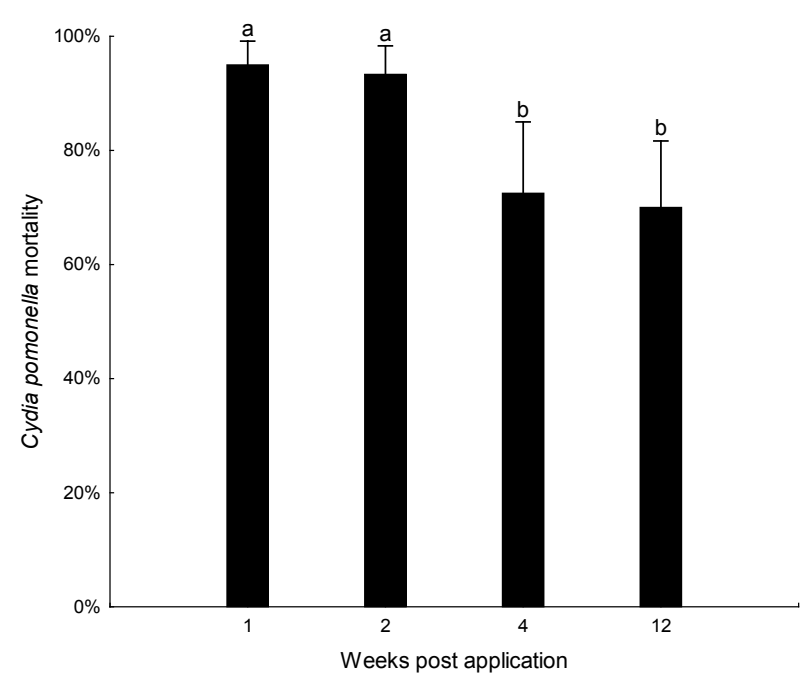

FIGURE 3

Percentage mortality (95\% confidence interval) of Cydia pomonella at the Welgevallen vineyard (Block A) buried $15 \mathrm{~cm}$ beneath the soil in the field with a five-day exposure to Steinernema yirgalemense after one, two, four and 12 weeks post EPN application (two-way ANOVA; $\mathrm{F}_{(3,84)}=$ 5.584; $P=0.002)$. Bars sharing a common letter are not significantly different.

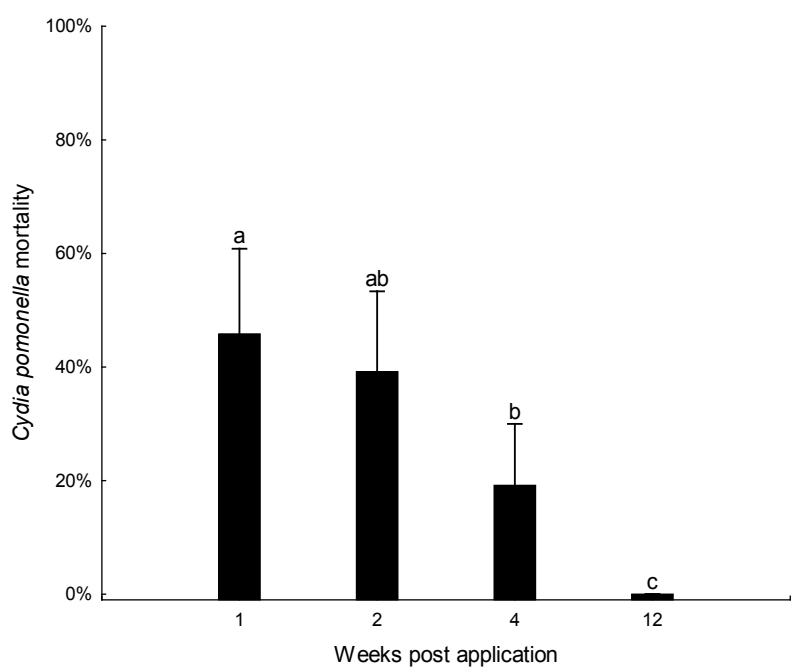

FIGURE 4

Percentage mortality (95\% confidence interval) of Cydia pomonella buried $15 \mathrm{~cm}$ beneath the soil in the field in Block $\mathrm{B}$ with a five- day exposure to Steinernema yirgalemense after one, two, four and 12 weeks post EPN application (twoway ANOVA; $\left.\mathrm{F}_{(3,84)}=10.230 ; P=0.0001\right)$. Bars sharing a common letter are not significantly different. 
as completely consumed, bitten or left intact. For both four- and six-day-old cadavers, $100 \%$ of control cadavers (freeze-killed individuals), $15 \%$ of $H$. zealandica and 5\% of $S$. yirgalemense had been consumed, whereas $0 \%$ of both had been consumed in the six-day-old $H$. zealandica and $S$. yirgalemense cadavers (Fig. 7). Of the four-day-old cadavers, $17 \%$ of $H$. zealandica and $29 \%$ of $S$. yirgalemense remained intact, whereas $60 \%$ and $49 \%$ of the six-day-old
$H$. zealandica and $S$. yirgalemense cadavers remained intact respectively (Fig. 7).

\section{Cue attraction response for $S$. yirgalemense}

From the results obtained on the movement of the IJs towards the three different arms of the olfactometer, no significant difference was found between the three test dates involved $(P=0.49)$. Data was pooled and a one-way ANOVA showed

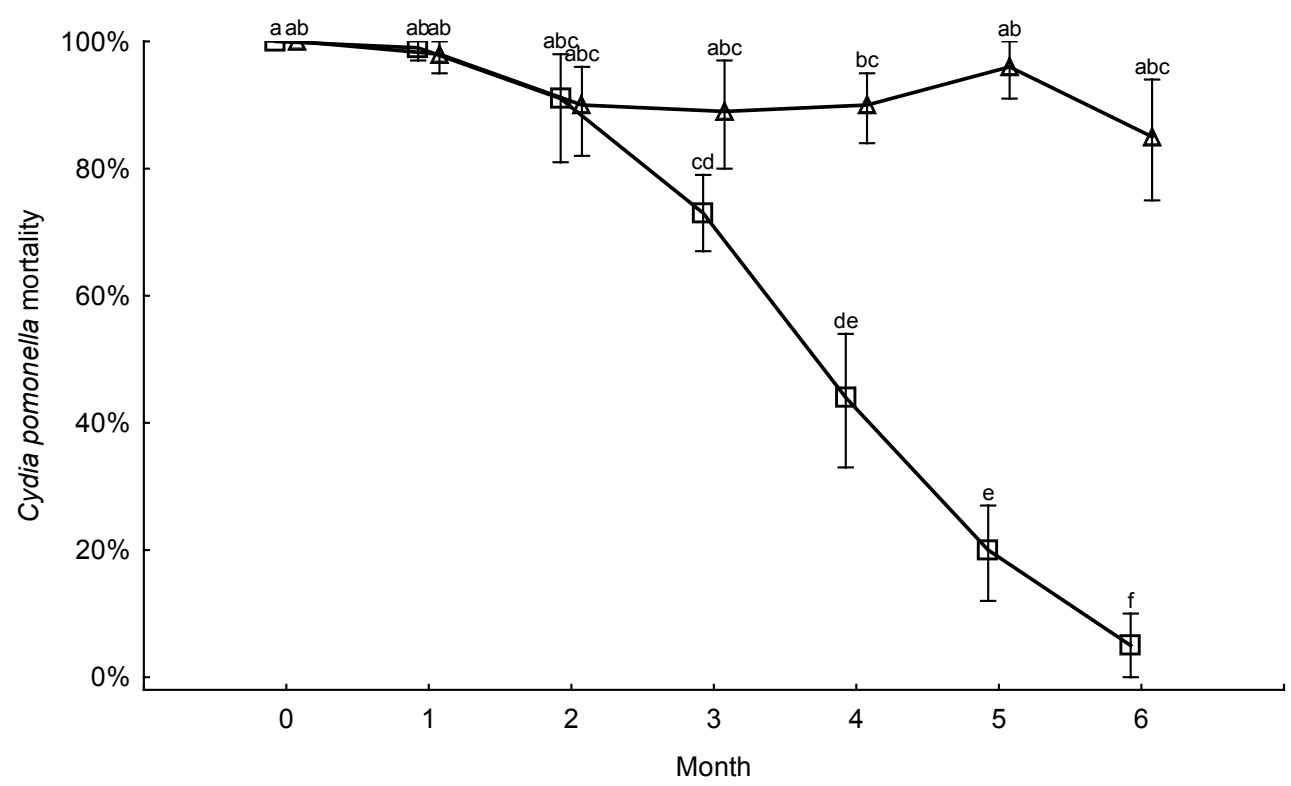

看 H. zealandica

FIGURE 5

Percentage mortality (95\% confidence interval) of Cydia pomonella exposed to $10 \mathrm{IJ} / \mathrm{cm}^{2}$ Heterorhabditis zealandica and Steinernema yirgalemense IJs after 0, 1, 2, 3 and 4 months persistence in sand (one-way ANOVA; $\mathrm{F}_{(4,90)}=18.342 ; P<0.001$ ). Different letters on bars indicate a significant difference.

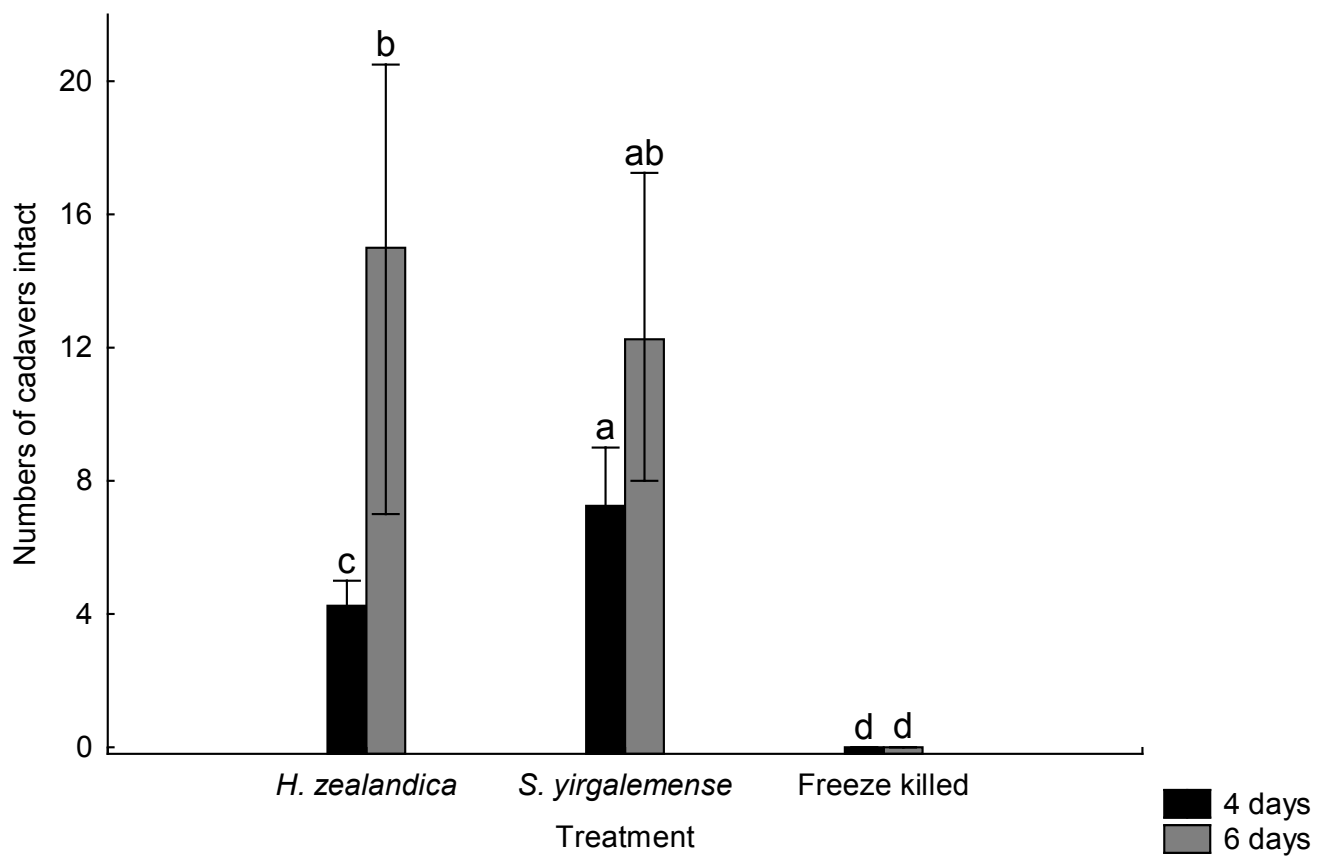

FIGURE 6

Percentage intact Cydia pomonella cadavers (95\% confidence interval) four and six days post Heterorhabditis zealandica and Steinernema yirgalemense inoculation after $24 \mathrm{~h}$ exposure to Linepithema humile (two-way ANOVA; Wald X² (2) = 23.363; P $<0.001)(95 \%$ confidence interval). Bars sharing a common letter are not significantly different. 


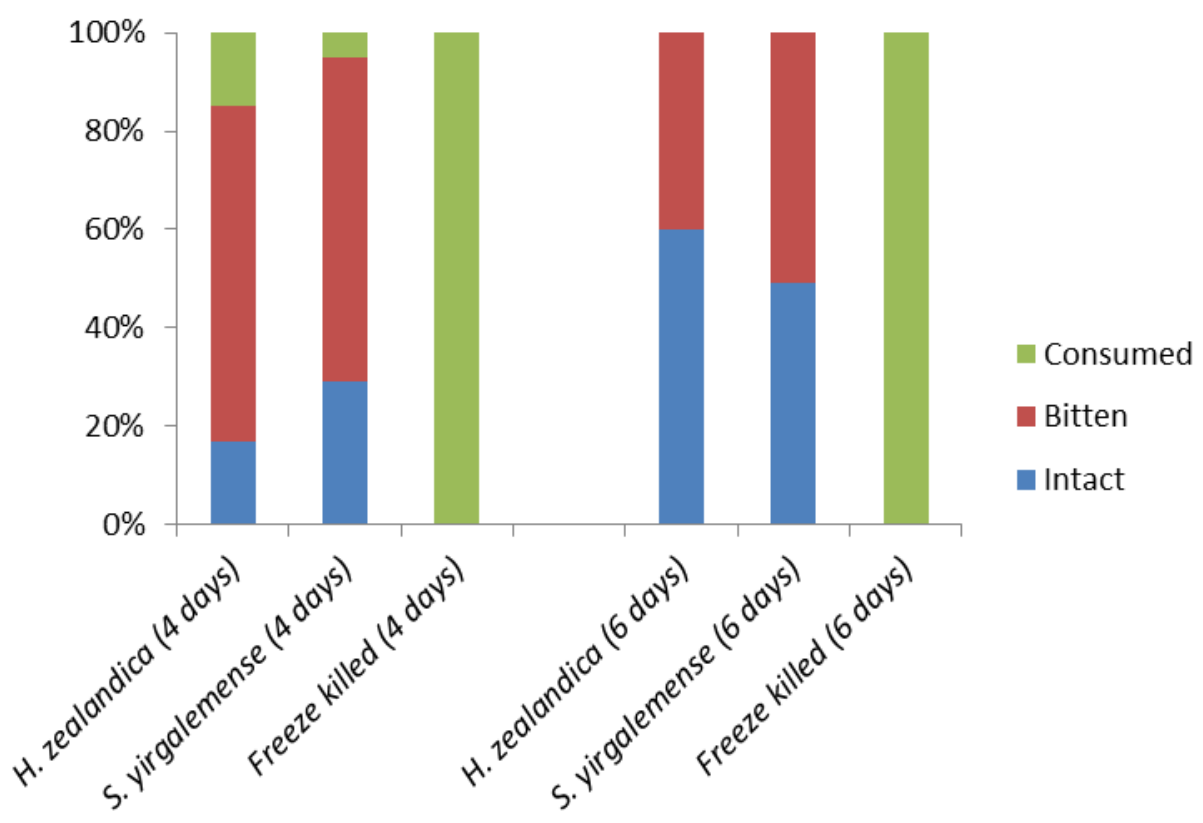

FIGURE 7

Percentages of four- and six-day-old Cydia pomonella cadavers infected with Heterorhabditis zealandica and Steinernema yirgalemense that were consumed, bitten or left intact after $24 \mathrm{~h}$ exposure to Linepithema humile.

significant overall effects between treatments (Wald $\mathrm{X}^{2}(2)$ $=23.363 ; \mathrm{P}<0.001)$. Significant differences were evident between the average numbers of IJs found having moved towards the control $(3.5 \pm 1.02 \mathrm{IJs})$, the grapevine roots $(246.4 \pm 0.124 \mathrm{IJs})$, and the mealybugs $(132.5 \pm 0.168 \mathrm{IJs})$ $(\mathrm{P}<0.05)$ (Fig. 8).

\section{DISCUSSION}

The two vineyards that were chosen to test the efficacy of controlling $P$. ficus in the soil using $S$. yirgalemense were analysed separately. In both instances, $S$. yirgalemense performed well, despite the fact that the mealybugs were left in the soil for only $48 \mathrm{~h}$, when, in practice, the nematode would have had an indefinite time period for infection. In addition to the above findings, the mealybugs were buried $15 \mathrm{~cm}$ beneath the soil, which means that the nematodes had to detect, and to infect, the insects within a short period of time. These are promising results when considering that, in South Africa, P. ficus spends the winter months in colonies on the lower trunk, under the bark and underground on the roots of the vine. This should make them more vulnerable targets to applied EPNs than in the experiment (De Villiers, 2006; Holm, 2008; Negrisoli et al., 2013).

To test the ability of $S$. yirgalemense to persist in the soil post-application, and due to the difficulty of working with P. ficus (because of its small size and sensitivity to handling), which might affect the data, codling moth larvae were buried in the soil. On the other hand, codling moth larvae are known for their susceptibility to $S$. yirgalemense (De Waal et al., 2011). The same treatment was applied to both vineyards, and the larvae were left in the soil for five days to provide any remaining IJs sufficient time to locate and infect the hosts. Generally speaking, as soon as EPNs are applied to the soil, they are exposed to an array of abiotic and biotic factors that cause nematode mortality (Curran, 1993). Some biotic factors include temperature, soil texture and soil moisture, while biotic factors include free-living macro- and microfauna and flora, among many others (Curran, 1993; Kaya \& Thurston, 1993). Over and above these many factors, some nematode species are known to be characteristically more persistent than others (Curran, 1993).

The persistence of $S$. yirgalemense in the two vineyards that were used in the current study differed dramatically, with a steady persistence in Block A, and a drastic decrease in Block B over the three months. The difference in the two vineyards could have been due to any of the many abiotic and biotic factors of the two vineyards. To hold one factor accountable for the low persistence in Block B would be almost impossible, as there might be a multitude of factors at work. To make comparisons and to draw conclusions from other persistence studies is also difficult, as different EPN species are studied under a variety of different conditions. Across studies, many different factors have been investigated and felt to be responsible for the decline in persistence time, which varied from a few days to a few months (Kung et al., 1990; 1991; Wilson \& Gaugler, 2004; Koppenhöfer \& Fuzy, 2006; 2007). One possible reason for the sturdy 'persistence' in Block A might be that the IJs could have been recycling, as considered by Curran (1993), thus finding hosts in the soil and continuing with their life cycle as opposed to persisting without available hosts. If this were the case, then the nematodes might establish themselves and, subsequently, improve in controlling the pest insect concerned (Kaya \& Stock, 1997). On the other hand, the large decline in the percentage of mortalities in the Block B vineyard between four and 12 weeks post-application may be due to the fact that, between these two periods, tillage had occurred between the grapevine rows. Work done by 
Susurluk and Ehlers (2008) found that ploughing caused a decline in $H$. bacteriophora persistence.

There are numerous reported cases of the persistence of EPNs, but the parameters for each differ concerning the strains and environmental conditions tested (Smits, 1996). As a result, a laboratory persistence trial for both $H$. zealandica and $S$. yirgalemense was conducted in the hope that comparable results could be produced for current and future studies. When investigating the persistence of nematodes in the field, results could possibly be influenced by the availability of insect hosts (Susurluk \& Ehlers, 2008). Consequently, in-field persistence studies will not be able to distinguish between the persistence of the released population of EPNs and the continuation of offspring from the released population, otherwise known as recycling (Curran, 1993; Susurluk \& Ehlers, 2008).

Favourable laboratory conditions were set up to establish the persistence under such conditions, providing a 'model' for comparison with other results. Although the current laboratory persistence trials extend only to six months, this is long enough to draw some conclusions. The use of codling moth mortality is an indirect measurement of persistence. To gain precise data on persistence, the original numbers of living IJs that were used to inoculate the containers would need to be known, and the number of live individuals would need to be washed from the medium and be counted at a given time. Such a process would be laborious and impractical to conduct. The decrease in the percentage of codling moth larvae mortality between two and six months as a result of $H$. zealandica infection indicates a reduction in the number of IJs persisting in the container. On the other hand, there still was a steady persistence of $S$. yirgalemense at 12 weeks, inferring its superiority to $H$. zealandica in its ability to persist. When comparing these results to those found in the field trials, it is evident that environmental conditions (be

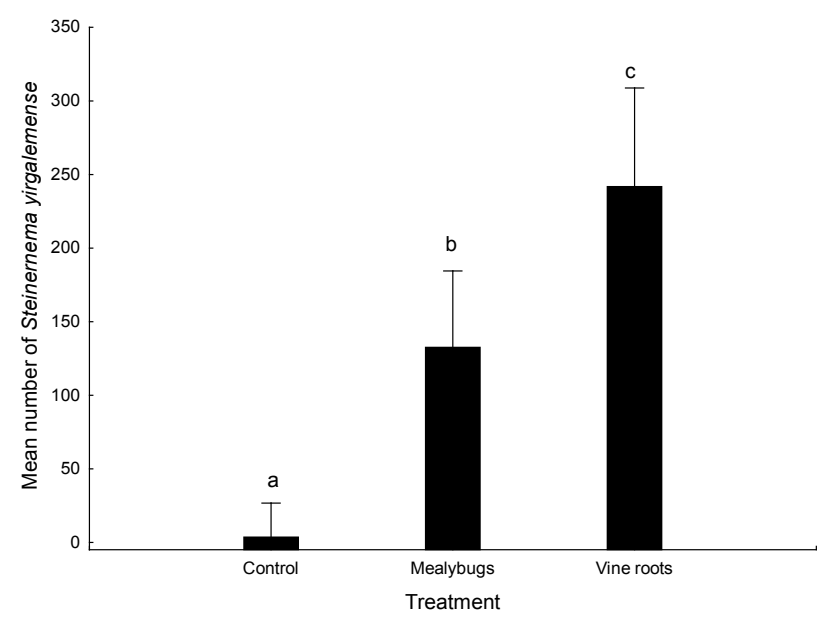

FIGURE 8

The mean number of Steinernema yirgalemense infective juveniles recovered from olfactometer arms connected to bulbs containing either adult Planococcus ficus females, grapevine roots or nothing, $24 \mathrm{~h}$ after inoculation (one-way ANOVA; Wald $\left.\mathrm{X}^{2}(2)=23.363 ; \mathrm{P}<0.001\right)(95 \%$ confidence interval). Bars sharing a common letter are not significantly different. they abiotic, biotic and/or anthropogenic) in Block B were less conducive to $S$. yirgalemense IJ persistence than in Block A. Not having counted the number of IJs present in the soil means that the longevity of the different EPN species over time could not be determined, but indications of persistence and insecticidal activity nevertheless were demonstrated.

Despite the current variations in field persistence studies and the differing techniques in laboratory persistence studies, contemporary work has been done that allows for the reliable identification and quantification of microorganisms in the soil. The use of quantitative real-time PCR (qPCR) can be used in the field and in the laboratory for identifying and quantifying EPN species (Campos-Herrera et al., 2012). Conventional insect baiting techniques can now be replaced by the qPCR method, which is faster, more accurate and more affordable (Campos-Herrera et al., 2011a; 2011b). Such a technique should be used for future persistence trials.

The need to test for the compatibility of EPNs and agrochemicals is important when considering the use of EPNs in an IPM scheme. Being able to tank-mix the EPNs and the desired agrochemical may economise the process, and might result in the improved control of a single pest (Koppenhöfer \& Grewal, 2005). Many studies have been done to determine the effects of different EPN species, in combination with agrochemicals such as insecticides, nematicides and acaricides (Koppenhöfer \& Grewal, 2005; Gutiérrez et al., 2008; Van Niekerk \& Malan, 2014).

The tests that were conducted for this study concerning both IJ survival and infectivity and using commercially available $H$. bacteriophora and $S$. feltiae, displayed no negative results for both factors. Studies conducted by Alumai and Grewal (2004) and by Koppenhöfer et al. (2000) found synergistic effects between $H$. bacteriophora and imidacloprid, while Alumai and Grewal (2004) also found that the combination significantly increased the pathogenicity of $H$. bacteriophora. The results obtained in this study could be considered to be additive instead of synergistic for both commercially available $H$. bacteriophora and $S$. feltiae, in terms of the findings of Koppenhöfer and Grewal (2005). The researchers describe additive results as being complementary due to the agents concerned acting independently of each other as opposed to synergistically, whereby the combination of the agents produces an increased efficacy in control (more so than if these results were simply added together). Based on this data, the mixture of the product imidacloprid and of the two EPN species concerned indicates compatibility, enabling tank mixtures to be made for co-application in an IPM programme for grapevines, which should reduce the costs and application time required. Commercially available $H$. bacteriophora and $S$. feltiae were tested, rather than $S$. yirgalemense, due to their availability and future commercial use in the field, while acknowledging that the effects of imidacloprid on S. yirgalemense would most likely be very similar. Local species are not currently available in South Africa in the quantities that would be needed for commercial application.

Ants involved in symbiotic relationships with mealybugs and other arthropod scavengers pose a threat to EPN population persistence and recycling, and might influence the choice of application methods in the field. It is critical 
that the cadaver infected with EPNs remains intact so as to enable the nematodes to complete their life cycle (Foltan \& Puza, 2009). Although insect cadavers are vulnerable to invertebrate scavengers, such as ants, studies have been conducted suggesting that the nematode/bacteria infestation might deter ants from scavenging (Foltan \& Puza, 2009). Zhou et al. (2002) used four-day-old G. mellonella larvae killed by different strains of Photorhabdus and Xenorhabdus species, or by freezing, and found that a significantly larger number of non-infected cadavers were removed by the ants. Using two- and eight-day-old G. mellonella larvae infected with different steinernematid and heterorhabditid nematodes, Baur et al. (1998) found that different ant species removed more steinernematid-infected cadavers (60 to 80\%) than heterorhabditid-infected larvae (10 to $20 \%$ ) within a period of $24 \mathrm{~h}$. Gulcu et al. (2012), in furthering the work done by Baur et al. (1998) and Zhou et al. (2002), extended their tests beyond ants to other arthropod scavengers, such as crickets, wasps and calliphorid flies. They found that the chemical compounds that are produced by the symbiotic bacteria of the EPNs not only deter ants from feeding on the cadavers, but also the insects tested, suggesting that the chemicals be called scavenger-deterrent factors rather than ant-deterrent factors.

Unfortunately, the current study concerning the possible deterrent factors produced by $H$. zealandica and $S$. yirgalemense produced results that displayed no significant difference between the infected cadavers that were bitten and consumed, and those that were left intact. This study should not be neglected, though, as the data suggest that there definitely are factors at work. In every instance the control cadavers that were freeze-killed had been entirely consumed, while, in most cases, the cadavers that were infected with either $H$. zealandica or with $S$. yirgalemense had either been left intact or bitten, but hardly ever entirely consumed. Of the cadavers that were presented six days after infection, $49 \%$ of those infected by $H$. zealandica and $60 \%$ of those infected by $S$. yirgalemense were left intact, which suggests the production of such scavenger-deterrent factors. Furthermore, the bitten cadavers might have been 'tested' by the ants and subsequently left alone due to the presence of the deterrent chemicals. However, the above still resulted in the cadavers drying out and the nematodes dying. In the soil, where humidity levels are likely to be much higher, the cadaver might remain hydrated after a bite, with the nematodes being left to complete their cycle.

According to Hunter (2001) there is a large gap in the understanding of below-ground herbivory and how roots are able to gain protection from herbivory through chemical defence mechanisms. As such, studies suggest that the defence mechanisms of roots might be the same as those that can be found in above-ground tissues (Hunter, 2001). There is increasing information that roots secrete chemicals that initiate dialogue between the plant roots and the soil microbes, so that infested plants have the ability to attract predators of the pest in what might be conceived of as a 'cry for help' (Hampel et al., 2005; Badri \& Vivanco, 2009). Communication with the surrounding environment is attained by utilising the release of volatile organic compounds. The volatile compounds that are mostly responsible for defence and resistance activities are known as terpenes and are biosynthesised by the roots, the function of which is an area that requires much more exploration (Hampel et al., 2005; Tholl, 2006).

$V$. vinifera is susceptible to many pathogens and is known to show few induced responses to attack (Kellow et al., 2004). Recently, Lawo et al. (2011) conducted the first comparative study on the production of volatile metabolites by uninfested plants and those infested by grape phylloxera, Daktulosphaira vitifoliae (Fitch), infested root tips of the grapevine. Nine terpenes were identified as being metabolites of the vine root, of which beta-caryophyllene was produced due to herbivore attack (Lawo et al., 2011). Considering that phylloxera are part of the Hemiptera, such as $P$. ficus, it is likely that the feeding of $P$. ficus on vine roots also would initiate the production of beta-caryophyllene. It is known that beta-caryophyllene, produced in response to insect herbivory on maize roots, strongly attracts the IJ of H. megidis (Rasmann et al., 2005).

The three-armed olfactometer designed for this study showed that artificially damaged $V$. vinifera roots attract a significantly larger number of $S$. yirgalemense IJs than $P$. ficus adult females. This test suggests two important ecological factors concerning $S$. yirgalemense. One is that it actively responds to host cues and moves towards the source of the organic compounds, which contrasts with the findings of De Waal et al. (2011). Secondly, S. yirgalemense has a greater attraction to volatiles produced by roots than those produced by the herbivore, $P$. ficus. In this instance it is fair to assume that $V$. vinifera could be involved (under natural conditions) in tritrophic interactions involving EPNs and insect herbivores such as $P$. ficus. An investigation by Laznik and Trdan (2013) showed that the foraging strategies of EPNs do not affect the movement of IJs towards volatile compounds, including beta-caryophyllene, produced by mechanically damaged maize roots. The results also suggest that responses to different volatile cues are more dependent on EPN strain-specific characteristics than on different search strategies (Laznik \& Trdan, 2013).

$S$. yirgalemense produced good results in the current soil field trials, having exposed the sensitivity of the soil-dwelling stages of P. ficus. Knowing the compatible use of EPNs with imidacloprid is important in an IPM scheme, as both can be applied simultaneously in the field with confidence, while increasing convenience with co-application and also reducing costs. These findings, with indicative results showing the possible production of scavenger-deterrent factors and the ability of $S$. yirgalemense to sense organic cues and actively seek out the source, places $S$. yirgalemense in a promising position as a potential biological agent for the control of $P$. ficus.

\section{LITERATURE CITED}

Addison, P., 2002. Chemical stem barriers for the control of ants (Hymenoptera: Formicidae) in vineyards. S. Afr. J. Enol. Vitic. 23, 1-8.

Alumai, A. \& Grewal, P.S., 2004. Tank-mix compatibility of the entomopathogenic nematodes, Heterorhabditis bacteriophora and Steinernema carpocapsae, with selected chemical pesticides used in turfgrass. Biocont. Sci. Technol. 14, 725-730. 
Badri, D.V. \& Vivanco, J.M., 2009. Regulation and function of root exudates. Plant Cell Environ. 32, 666-681.

Baur, M.E., Kaya, H.K. \& Strong, D.R., 1998. Foraging ants as scavengers on entomopathogenic nematode-killed insects. Biol. Contr. 12, 231-236.

Bird, A.F. \& Bird, J., 1986. Observations on the use of insect parasitic nematodes as a means of biological control of root-knot nematodes. J. Parasitol. 16, 511-516.

Boemare, N., 2001. Interactions between the partners of entomopathogenic bacterium nematode complexes, Steinernema-Xenorhabdus and Heterorhabditis-Photorhabdus. Nematol. 4, 601-603.

Boff, M.I.C., Zoon, F.C. \& Smits, P.H., 2001. Orientation of Heterorhabditis megidis to insect hosts and plant roots in a Y-tube sand olfactometer. Entomol. Exp. Appl. 98, 329-337.

Campos-Herrera, R., El-Borai, F.E., Stuart, R.J., Graham, J.H. \& Duncan, L.W., 2011a. Entomopathogenic nematodes, phoretic Paenibacillus spp., and the use of real time quantitative PCR to explore soil food webs in Florida citrus groves. J. Invert. Pathol. 108, 30-39.

Campos-Herrera, R., Johnson, E.G., El-Borai, F.E., Stuart, R.J., Graham, J.H. \& Duncan, L.W., 2011b. Long-term stability of entomopathogenic nematode spatial patterns in soil as measured by sentinel insects and realtime PCR assays. Ann. Appl. Biol. 158, 55-68.

Campos-Herrera, R., El-Borai, F.E. \& Duncan, L.W., 2012. Wide interguild relationships among entomopathogenic and free-living nematodes in soil as measured by real time qPCR. J. Invert. Pathol. 111, 126-135.

Choo, H.Y., Kaya, H.K., Burlando, T.M. \& Gaugler, R., 1989. Entomopathogenic nematodes: Host-finding ability in the presence of plant roots. Environ. Entomol. 18, 1136-1140.

Curran, J., 1993. Post-application biology of entomopathogenic nematodes in soil. In: Bedding, R., Akhurst, R. \& Kaya, H.K. (eds). Nematodes and the biological control of insect pests. CSIRO, East Melbourne. pp. $67-77$.

Daane, K.M., Bently, W.J., Walton, V.M., Malakar-Kuenen, R., Millar, J.G., Ingels, C., Weber, E. \& Gispert, C., 2006. New controls investigated for vine mealybug. Calif. Agr. 60, 31-38.

Daane, K.M., Cooper, M.L., Triapitsyn, S.V., Walton, V.M., Yokota G.Y., Haviland, D.R., Bentley, W.J., Godfrey, K. \& Wunderlich, L.R., 2008. Vineyard managers and researchers seek sustainable solutions for mealybugs, a changing pest complex. Calif. Agr. 62, 167-176.

De Villiers, M., 2006. Development of a pest management system for table grapes in the Hex River Valley. Dissertation, Department of Conservation Ecology and Entomology, Stellenbosch University, Private Bag X1, Matieland (Stellenbosch), South Africa.

De Waal, J.Y, Malan, A.P. \& Addison, M.F., 2011. Efficacy of entomopathogenic nematodes (Rhabditida: Heterorhabditidae and Steinernematidae) against codling moth, Cydia pomonella (Lepidoptera: Tortricidae) in temperate regions. Biocont. Sci. Technol. 21, 1161-1176.

Duncan, L.W., Graham, J.H.Z.J., Bright, D., Dunn, D.C., El Borai, F.E. \& Porazinska, D.L., 2007. Food web responses to augmenting the entomopathogenic nematodes in bare and animal manure-mulched soil. J. Nematol. 39, 176-189.

Efron, B. \& Tibshirani, R., 1993. An introduction to the bootstrap. Chapman and Hall, London.

Ehlers, R., 2001. Mass production of entomopathogenic nematodes for plant protection. Appl. Microb. Technol. 56, 623-633.

Flaherty, D.L., Peacock, W.L., Bettiga, L. \& Leavitt, G.M., 1982. Chemicals losing effect against grape mealybug. Calif. Agr. 36, 6 .
Foltan, P. \& Puza, V., 2009. To complete their life cycle, pathogenic nematode-bacteria complexes deter scavengers from feeding on their host cadaver. Behav. Process. 80, 76-79.

Franco, J.C., Zada, A. \& Mendel, Z., 2009. Novel approaches for the management of mealybug pests. In: Ishaaya, I. \& Horowitz, A.R. (eds). Biorational control of arthropod pests - application and resistance management. Springer Science, New York. pp. $233-278$.

García del Pino, F. \& Jové, M., 2005. Compatibility of entomopathogenic nematodes with fipronil. J. Helminthol. 79, 333-337.

Grewal, P.S., Lewis, E.E., Gaugler, R. \& Campbell, J.F., 1994. Host finding behaviour as a predictor of foraging strategy in entomopathogenic nematodes. Parasitol. 108, 207-215.

Griffin, C.T., Boemare, N.E. \& Lewis, E.E., 2005. Biology and behaviour. In: Grewal, P.S., Ehlers, R.U. \& Shapiro-Ilan, D.I. (eds). Nematodes as biocontrol agents. CABI Publishing, Wallingford, UK. pp. $47-75$.

Gulcu, B., Hazir, S. \& Kaya, H.K., 2012. Scavenger deterrent factor (SDF) from symbiotic bacteria of entomopathogenic nematodes. J. Invert. Pathol. $110,326-333$

Gutiérrez, C., Campos-Herrera, R. \& Jiménez, J., 2008. Comparative study of the selected agrochemical products on Steinernema feltiae (Rhabditida: Steinernematidae). Biocont. Sci. Technol. 18, 101-108

Hampel, D., Mosandl, A. \& Wust, M., 2005. Induction of de novo volatile terpene biosynthesis via cytosolic and plastidial pathways by methyl jasmonate in foliage of Vitis vinifera L. J. Agric. Food Chem. 53, 2652 2657.

Haviland, D.R., Bentley, W.J. \& Daane, K.M., 2005. Hot water treatments for control of Planococcus ficus (Homoptera: Pseudococcidae) on dormant grape cuttings. Econ. Entomol. 98, 1109-1115.

Hazir, S., Kaya, H.K., Stock, S.P. \& Keskin, N., 2003. Entomopathogenic nematodes (Steinernematidae and Heterorhabditidae) for biological control of soil pests. Turk. J. Biol. 27, 181-202.

Holm, K., 2008. Construction of a cDNA library for the vine mealybug, Planococcus ficus (Signoret). Thesis, Department of Conservation Ecology and Entomology, Stellenbosch University, Private Bag X1, Matieland (Stellenbosch), South Africa.

Hunter, M.D., 2001. Out of sight, out of mind: The impacts of root-feeding insects in natural and managed systems. Agric. Forest Entomol. 3, 3-9.

Kaya, H.K., 2002. Natural enemies and other antagonists. In: Gaugler, R. (ed.). Entomopathogenic nematology. CAB International, Wallingford, UK. pp. $189-199$.

Kaya, H.K. \& Gaugler, R., 1993. Entomopathogenic nematodes. Annu. Rev. Entomol. 38, 181-202.

Kaya, H.K. \& Stock, S.P., 1997. Techniques in insect nematology. In: Lacey, L.A. (ed.). Manual of techniques in insect pathology. Academic Press, London. pp. $281-301$

Kaya, H.K. \& Thurston, G.S., 1993. Soil microorganisms affecting entomopathogenic nematodes. In: Bedding, R., Akhurst, R. \& Kaya, H. (eds). Nematodes and the biological control of insect pests. CSIRO Publications, Collingwood, VA. pp 97 - 104.

Kellow, A.V., Sedgley, M. \& Van Heeswijck, R., 2004. Interaction between Vitis vinifera and grape phylloxera: Changes in root tissue during nodosity formation. Ann. Bot. 93, 581-590.

Koppenhöfer, A.M. \& Grewal, P.S., 2005. Compatibility and interaction with agrochemicals and other biocontrol agents. In: Grewal, P.S., Ehlers, R.-U. \& Shapiro-Ilan, D.I. (eds). Nematodes as biocontrol Agents. CAB International, Wallingford, UK. pp. $363-378$ 
Koppenhöfer, A.M. \& Fuzy, E.M., 2006. Effect of soil type on infectivity and persistence of entomopathogenic nematodes Steinernema scarabaei, Steinernema glaseri, Heterorhabditis zealandica and Heterorhabditis bacteriophora. J. Invertebr. Pathol. 92, 11-12.

Koppenhöfer, A.M. \& Fuzy, E.M., 2007. Soil moisture effects on infectivity and persistence of entomopathogenic nematodes Steinernema scarabaei, S. glaseri, Heterorhabditis zealandica and H. bacteriophora. Appl. Soil Ecol. $35,128-139$.

Koppenhöfer, A.M., Brown, I.M., Gaugler, R., Grewal, P.S., Kaya, H.K., Klein \& M.G., 2000. Synergism of entomopathogenic nematodes and imidacloprid against white grubs: Greenhouse and field evaluation. Biol. Contr. 19, 245-251.

Kung, S., Gaugler, R. \& Kaya, H.K., 1990. Soil type and entomopathogenic nematode persistence. J. Invert. Pathol. 55, 401-406.

Kung, S., Gaugler, R. \& Kaya, H.K., 1991. Effects of soil temperature, moisture, and relative humidity on entomopathogenic nematode persistence. J. Invert. Pathol. 57, 242-249.

Lawo, N.C., Weingart, G.J.F., Schuhmacher, R. \& Forneck, A., 2011. The volatile metabolome of grapevine roots: First insights into the metabolic response upon Phylloxera attack. Plant Physiol. Bioch. 49, 1059-1063.

Laznik, Z. \& Trdan, S., 2013. An investigation on the chemotactic responses of different entomopathogenic nematode strains to mechanically damaged maize root volatile compounds. Exp. Parasitol. 13, 349-355.

Lei, Z., Rutherford, T.A. \& Webster, J.M., 1992. Heterorhabditid behaviour in the presence of the cabbage maggot, Delia radicum, and its host plants. J. Nematol. 24, 9-15.

Le Vieux, P.D. \& Malan, A.P., 2013a. Entomopathogenic nematodes for the control of the vine mealybug (Planococcus ficus) in South African wine and table grapes: A review. S. Afr. J. Enol. Vitic. 34, 108-118.

Le Vieux, P.D. \& Malan, A.P., 2013b. The potential use of entomopathogenic nematodes to control Planococcus ficus (Signoret) (Hemiptera: Pseudococcidae). S. Afr. J. Enol. Vitic. 34, 296-306.

Lewis, E.E., Campbell, J., Griffin, C., Kaya \& H., Peters, A., 2006. Behavioural ecology of entomopathogenic nematodes. Biol. Contr. 38, 6679.

Lewis, E.E., Gaugler, R. \& Harrison R., 1993. Response of cruiser and ambusher entomopathogenic nematodes (Steinernematidae) to host volatile cues. Can. J. Zool. 71, 765-769.

Malan, A.P., Knoetze, R. \& Moore, S.D., 2011. Isolation and identification of entomopathogenic nematodes from citrus orchards in South Africa and their biocontrol potential against false codling moth. J. Invert. Pathol. 108, 115-125.

Malan, A.P., Nguyen, K.B. \& Addison, M.F., 2006. Entomopathogenic nematodes (Steinernematidae and Heterorhabditidae) from the southwestern parts of South Africa. Afr. Plant Prot. 12, 65-69.

Mgocheki, N. \& Addison, P., 2009. Interference of ants (Hymenoptera: Formicidae) with biological control of the vine mealybug Planococcus ficus (Signoret) (Hemiptera: Pseudococcidae). Biol. Contr. 49, 180-185.
Negrisoli, C.R.C.B., Nergisoli, A.S., Botton, M., Garcia, M.S. \& Bernardi, D., 2013. Evaluation of efficacy of 18 strains of entomopathogenic nematodes (Rhabditida) against Planococcus citri (Risso, 1813) (Hemiptera: Pseudococcidae) under laboratory conditions. Exp. Parasitol. 134, 295-298.

Nguyen, K.B., Hunt, D.J. \& Mrácek, Z., 2007. Steinernematidae: Species descriptions. In: EDITORS? Entomopathogenic nematodes: Systematics, phylogeny and bacterial symbionts. Brill, Leiden-Boston. pp. 121-609.

Phillips, P.A. \& Sherk, C.J., 1991. To control mealybugs, stop honeydewseeking ants. Calif. Agr. 45, 26-28

Rasmann, S., Kollner, T.G., Degenhardt, J., Holtpold, I., Toepfer, S., Kuhlmann, U., Gershenzon, J. \& Turlings, C.J., 2005. Recruitment of entomopathogenic nematodes by insect-damaged maize roots. Nature 434, $732-737$.

Shapiro-Ilan, D.I., Gouge, D.H., Piggott, S.J. \& Fife, J.P., 2006. Application technology and environmental considerations for use of entomopathogenic nematodes in biological control. Biol. Control 38, 124-133.

Smits, P.H., 1996. Post-application persistence of entomopathogenic nematodes. Biocontrol Sci. Techn. 6, 379-387.

StatSoft, Inc., 2012. STATISTICA (data analysis software system), version 11. www.statsoft.com

Susurluk,A. \& Ehlers, R.-U., 2008. Field persistence of the entomopathogenic nematode Heterorhabditis bacteriophora in different crops. Biocontrol 53, 627-641.

Tholl, D., 2006. Terpene synthases and the regulation, diversity and biological roles of terpene metabolism. Curr. Opin. Plant Biol. 9, 297-304.

Van Niekerk, S. \& Malan, A.P., 2014. Compatibility of Heterorhabditis zealandica and Steinernema yirgalemense with agrochemicals and biological control agents. Afri. Entomol. 22, 49-56.

Van Tol, R.W.H.M., Van der Sommen, A.T.C., Boff, I.C., Van Bezooijen, J., Sabelis, M.W. \& Smits, P.H., 2001. Plants protect their roots by alerting the enemies of grubs. Ecol. Lett. 4, 292-294.

Walton, V.M., 2003. Development of an integrated pest management system for vine mealy bug, Planococcus ficus (Signoret), in vineyards in the Western Cape Province, South Africa. Dissertation, Department of Conservation Ecology and Entomology, Stellenbosch University, Private Bag X1, Matieland (Stellenbosch), South Africa.

Walton, V.M. \& Pringle, K.L., 2004a. A survey of mealybugs and associated natural enemies in the vineyards in the Western Cape province, South Africa. S. Afr. J. Enol. Vitic. 25, 23-25

Walton, V.M. \& Pringle, K.L., 2004b. Vine mealybug, Planococcus ficus (Signoret) (Hemiptera: Pseudococcidae), a key pest in South African vineyards: A review. S. Afr. J. Enol. Vitic. 25, 54-62.

Walton, V.M., Daane, K.M. \& Pringle, K.L., 2004. Monitoring Planococcus ficus in South African vineyards with sex pheromone-baited traps. Crop Prot. 23, 1089-1096.

Wilson, M. \& Gaugler, R., 2004. Factors limiting short-term persistence of entomopathogenic nematodes. J. Appl. Entomol. 128, 250-253.

Zhou, X., Kaya, H.K., Heungens, K. \& Goodrich-Blair, H., 2002. Response of ants to a deterrent factor(s) produced by the symbiotic bacteria of entomopathogenic nematodes. Appl. Environ. Microbiol. 68, 6202-6209. 